Simpson, J. R. (2018) Hearing and regarding animal pain in Heinrich's Reinhart Fuchs and Kaulbach's Reineke Fuchs illustrations. Oxford German Studies, 47(1), pp. 17-34. (doi: $10.1080 / 00787191.2018 .1409507$ )

There may be differences between this version and the published version. You are advised to consult the publisher's version if you wish to cite from it.

http://eprints.gla.ac.uk/150929/

Deposited on: 1 November 2017

Enlighten - Research publications by members of the University of Glasgow http://eprints.gla.ac.uk 


\section{Hearing and Regarding Animal Pain in Heinrich's Reinhart Fuchs and Kaulbach's Reineke Fuchs Illustrations}

James Simpson, University of Glasgow

This article considers representations of animal suffering, examining the cultural and political ramifications of images showing the mortal pain and fear of 'lesser' creatures. Relations between pathos and comedy can provide insights into the importance accorded either voice or vision in ethical appeal. Beginning with the poisoning of king Vrevel in the twelfth-century Reinhart Fuchs, an episode without precedent or analogue in the fox tradition, this article explores the legacies of reflection on animal identity and suffering across versions of the animal epic. As a later counterpoint to Heinrich's verbal evocation, the piece examines the playfully savage silencing and debasement of animal tongues in Wilhelm von Kaulbach's illustrations for the 1846 edition of Goethe's Reineke Fuchs. Insofar as Vrevel's death is an (animal) end of empire, the article also shows how the function of animals in Carolingian ideologies finds echo in later sources and suggests possibilities for further reflection.

Keywords: animals, beast, Heinrich ('der Glichezare'), Wilhelm von Kaulbach, Goethe, Hincmar of Reims, ethics, orality, pathos, tragi-comedy, Charlemagne, Carolingian

Der kvnic weinende sprach:

daz er Reinharten ie gesach:

'Des han ich verlorn min leben.

owe, er hat mir gift gegeben

Ane schvlde: ich han im niht getan. 
minen edelen kaplan

Hiez ich schinden dvrch sinen rat.

swer sich an den vngetruwen lat,

Dem wirt iz leit, des mvz ich iehen:

alsam ist ovch nv mir geschehen.'

Er kerte sich zV der wende,

do nam der kvnic sin ende:

Sin hovbet im en drev spielt

in nevne sich sin zvnge vielt.

Sie weinten alle dvrch not

umbe des edelen kvniges tot,

Si dreuweten alle harte

dem gvten Reinharte. (Reinhart Fuchs, 11. 2231-48) ${ }^{1}$

The King spoke, bewailing the fact he ever set eyes on Reinhart: 'I have forfeited my life on account of it. Woe is me: he has poisoned me when I was guiltless: I did him no wrong. My noble chaplain I had flayed at his behest. Whoever has truck with disloyalty will suffer for it - to this I must attest, for the same has befallen me.' He turned to the wall and there met his end. His head split into three and his tongue into nine. All wept

${ }^{1}$ For text, see Der 'Reinhart Fuchs' des Elsässers Heinrich, ed. by Klaus Düwel with Katharina von Goetz, Frank Henrikvark and Sigrid Krause, Altdeutsche Textbibliothek, 96 (Tübingen: Niemeyer, 1984). For a discussion of Heinrich's handling of his probable sources, see John Flinn, Le 'Roman de Renart' dans les littératures étrangères au Moyen Age, University of Toronto Romance Series, 4 (Toronto: University of Toronto Press, 1963), pp. 549-99. 
for grief at the noble king's death and made dire threats against good Reinhart. (trans. J.S.)

Nach Karl dem Grossen wurde das Reich geteilt und zerfiel. ${ }^{2}$

Heinrich's striking vision of the death of the lion-king Vrevel takes the motif of the sick lion treated by the fox's bogus medicine to its logical conclusion. ${ }^{3}$ As part of what critics have identified as Reinhart Fuchs's specular character, the narrative looks askance at both its place in literary tradition and at the moral and political questions foregrounded by treachery and murder. ${ }^{4}$ In a moment unique in the French and Germanic traditions, regicide supplants cure, destroying and fragmenting both body and body politic in an apocalyptic end of empire. ${ }^{5}$

${ }^{2}$ Georg Wilhelm Friedrich Hegel, Vorlesungen über die Philosophie der Weltgeschichte (Berlin 1822/1823): Nachschriften von Karl Gustav Julius von Griesheim; Henrich Gustav Hotho and Friedrich Carl Hermann Victor von Kehler, ed. by Karl Heinz Ilting, Karl Brehmer and Hoo Nam Seelmann, Georg Wilhelm Friedrich Hegel Vorlesungen: ausgewählte Nachschriften und Manusckripte, 12 (Hamburg: Meiner, 1996), p. 463.

${ }^{3}$ On the naming of the author see Der 'Reinhart Fuchs' des Elsässers Heinrich, ed. by Düwel et al., pp. xxi-xxii.

${ }^{4}$ Michael Schilling, 'Vulpekuläre Narrativik: Beobachtungen zum Erzählen im Reinhart Fuchs', Zeitschrift für deutsches Altertum und deutsche Literatur, 118:2 (1989), 108-22. See also Jean-Marc Pastré, 'Morals, Justice and Geopolitics in the Reinhart Fuchs of the Alsatian Heinrich der Glichezaere', in Reynard the Fox: Social Engagement and Cultural Metamorphoses in the Beast Epic from the Middle Ages to the Present, ed. by Kenneth Varty (Oxford: Berghahn, 2000), pp. 37-54.

${ }^{5}$ On the scene and its socio-political resonances, see Jurgen Kühnel, 'Zum Reinhart Fuchs als antistaufischer Gesellschaftssatire', in Stauferzeit: Geschichte, Literatur, Kunst, ed. by Rüdiger Krohn, Bernd Thum, Peter Wapnewski, Karlsruher kulturwissenschaftliche Arbeiten, 1 (Stuttgart: Klett-Cotta, 1978), pp. 71-86; Klaus Speckenbach, 'Der 
Heinrich's dark tragi-comedy thereby also underscores the complexities inherent in constructing animal fictions. Reinhart presents a distinction between inherent quality or nature - goodness especially - and exemplary significance as a 'Bild', creating a hall of mirrors in which the fox appears less evil incarnate than a paradoxically salutary manifestation of ambiguity befitting the very image of faithlessness ('untriuwe'). ${ }^{6}$

Here the beast epic raises wider philosophical questions: what are the feelings of animals themselves as opposed to our own imputations? And, how do we understand our own human animality? Accordingly, Vrevel's death scene reflects the awareness, manifest in both literary convention and evidence of experience, of the reality that for everyone - however powerful or rich in kin - death is an absolute solitude. ${ }^{7}$ And here it is salient that we are

Reichsuntergang im Reinhart Fuchs und in der Nibelungendichtung', in Third International Beast Epic, Fable and Fabliau Colloquium (Münster 1979): Proceedings, ed. by Jan Goossens and Timothy Sodmann, Niederdeutsche Studien 30 (Cologne: Böhlau, 1981), pp. 404-34; Sigrid Widmaier, Das Recht im 'Reinhart Fuchs', Quellen und Forschungen Germanistik, 107 (Berlin: de Gruyter, 1993), pp. 217-27; Jean-Marc Pastré, 'Une image de la fin des temps: la mort du roi Vrevel dans le Reinhart Fuchs', in Fin des temps et temps de la fin dans l'univers médiéval, Senefiance, 33 (Aix-en-Provence, Centre universitaire d'études et de recherches médiévales d'Aix, 1993), pp. 343-55.

${ }^{6}$ Karl-Heinz Göttert, Tugendbegriff und epische Struktur in höfischen Dichtungen: Heinrichs des Glîchezâre 'Reinhart Fuchs' und Konrads von Würzburg 'Englehard', Kölner germanistische Studien, 5 (Cologne: Böhlau, 1971). See also Alison Williams, Tricksters and Pranksters: Roguery in French and German Literature of the Middle Ages and the Renaissance, Internationale Forschungen zur allgemeinen und vergleichenden Literaturwissenschaft (Amsterdam: Rodopi, 2000).

${ }^{7}$ On which point see for instance the account of the death of Baldwin V of Hainault in Georges Duby and Philippe Ariès (eds), A History of Private Life: II - Revelations of the Medieval World, trans. by Arthur Goldhammer (Cambridge MA: Belknap and Harvard University Press, 1988), pp. 82-83. 
invited to hear and see the spectacle of a dying animal. Vrevel's speech follows the tropes of monologue and the expression of pain as he addresses his audience, attesting emphatically ('des mvz ich iehen', 1. 2239) and through tears (1.2231) to his innocence and Reinhart's malice. Poignantly, his animal words give human voice to a common fate in a manner whose implications are multifaceted: even as language loses its bridge-building capacity, the creaturely commonality marked here has the potential to cut across all notions of social or species exceptionalism: 'For we know that the whole creation groaneth and travaileth in pain together until now' (Romans 8.22). ${ }^{8}$ In that sense, to reprise a title chosen by Karl Steel, what we learn from Vrevel is that how we 'make a human' is to construct the kind of truly authentic ethical relation that would allow an animal to speak, be heard, and be seen. ${ }^{9}$ This article takes as its focus some arguably connected and usefully comparable representations of animal violence and suffering, in which respect, my principal sources are Heinrich's late twelfth-century Reinhart Fuchs, the Middle Dutch Van den vos Reynaerde (somewhat uncertainly dated to about 1260) and Kaulbach's illustrations for the 1846 edition of Goethe's Reineke Fuchs. ${ }^{10}$ My argument deals mainly with the comparisons that emerge from the

${ }^{8}$ On the emotive dimension of animal ethics and creaturely life, see Jerome Bump, 'Biophilia and Emotive Ethics: Derrida, Alice and Animals', Ethics and the Environment, 19 (2014), 57-89. As Bump points out, the verse is cited by Lewis Carroll in his essay 'Vivisection as a Sign of the Times', Pall Mall Gazette, 12 February 1875, p. 170. On the German Middle Ages specifically in this regard, see Udo Friedrich, Menschentier und Tiermensch: Diskurse der Grenzziehung und Grenz-überschreitung im Mittelalter, Historische Semantik 5 (Göttingen: Vandenhoeck and Ruprecht, 2009).

${ }^{9}$ Karl Steel, How to Make a Human: Animals and Violence in the Middle Ages, Interventions: New Studies in Medieval Cultures (Ohio: Ohio State University Press, 2011).

${ }^{10}$ For editions, see Of Reynaert the Fox / Van den vos Reynaerde, ed. by André Bouwman and Bart Besamusca, trans. by Thea Summerfield (Amsterdam: Amsterdam University Press, 
death or suffering of the lion king and the fox's bogusly judicial murder of the hare, these scenes providing a basis for exploring various ethical and aesthetic questions raised by the graphic representation of animal suffering in the beast epic tradition. Problems here include the issues raised by the tragi-comic misfiring of appeals to pathos in animal fictions, and the differences between verbal and visual expression. With these questions in mind, let us now return to Heinrich's Reinhart Fuchs.

The rhetorical layering of Vrevel's lament in is dense and deceptive. In a work cruelly untrue in its derision, Heinrich's presentation suggests that successive blindnesses betray the apparent tragedy, taking us into the realm of tragi-comedy. As a victim of his own folly and greed, Vrevel's wail that his fate is undeserved ('ane schvlde', 1. 2235) is problematic, as is the narrator's description of Reinhart as 'good' (1. 2248). Then there is the lion's ambiguous name, which can be understood positively or negatively. ${ }^{11}$ In the same way, the difference between the lion and other lamenting animals lies in his status as an apex predator: although his death is perhaps less banal perhaps than that of a chicken, in other respects no different. Moreover, a creature that has lived by - and in this case commanded - the death of others has limited right of complaint. Stepping back further, the rhetorical contrivance also offers a sly denunciation of oral appeal in written texts scripted 'fictitiously' in advance rather than being

2009) and Johann Wolfgang von Goethe, Reineke Fuchs, illustrated by Wilhelm von Kaulbach, engravings by R. Rahn and A. Schleich (Stuttgart: Cotta, 1846; repr. Wiesbaden and Luxembourg: Ebeling, 1976). For a brief account of Goethe's sources and context, see Nicholas Boyle, Goethe: The Poet and the Age: Volume II - Revolution and Renunciation (1790-1803) (Oxford: Clarendon, 2000), pp. 150-51.

${ }^{11}$ An ambiguity reflected in Vrevel's very name, which has no analogue elsewhere in the tradition, the term denoting both positive characteristics (courage) and negative ones (e.g. tyranny). See Widmaier, Das Recht im 'Reinhart Fuchs', p. 126. 
genuinely spontaneous responses to situations. ${ }^{12}$ More radically, insofar as he is nothing more than an absurd fiction lamenting itself, any potential sentiment is fatally punctured by what Paul Wackers presents as the genre's central incongruity: 'in real life, animals never speak'.13

Wackers' deadpanning here has resonance for later discussions about animals in literature, or indeed about animal rights in general: animals are mute in the measure that humans do not accord them a life of commensurate value. Clinging to the illusion that he is or is about to have been $-\mathrm{a}$ (speaking) subject endowed with human value, the King becomes a tragi-comic cousin to the cartoon cat walking off a cliff. However, unlike Vrevel, the cat realizes its mistake and does not typically die. And if it did, presumably we would not laugh. Though of course cats are by no means the only suffering animals in the beast epic.

\section{Visions of Animal Suffering}

Ende Cuaert riep ghenadelike:

'Helpt mi, Belin! Waer sidi?

Dese peelgrijn verbijt mi!'

Dat roupen was sciere ghedaen,

${ }^{12}$ On fictions of orality in the German tradition, see D. H. Green, Medieval Listening and Reading: The Primary Reception of German Literature 800-1300 (Cambridge: Cambridge University Press, 1994), p. 77-79.

${ }^{13}$ Paul Wackers, 'Words and Deeds in the Reynaert Stories', in Medieval Dutch Literature in its European Context, ed. by Erik Kooper, Cambridge Studies in Medieval Literature, 21 (Cambridge: Cambridge University Press, 1994), pp. 131-47, p. 131. On the relation between ethics and cyclical structure in the Renart material, see notably Luke Sunderland, Old French Narrative Cycles: Heroism between Ethics and Morality, Gallica, 15 (Cambridge: Brewer, 2010). 
bedi Reynaert hadde saen

sine kele ontwee ghebeten.

Doe sprac Reynaert: 'Nu gaen wi heten

desen goeden vetten hase.'

Die welpine liepen ten ase

ende ghinghen heten al ghemeene.

Haren rauwe was wel cleene

dat Cuaert hadde verloren tlijf. (11. 3121-32) $)^{14}$

And Cuwaert shouted pitifully: 'Help me, Belin! Where are you? This pilgrim is biting me to death!' The shouting soon ceased, for Reynaert had straightaway bitten his throat asunder. Then Reynaert said: 'Now let us eat of this good, fat hare.' The cubs ran to the food and started to eat together. They did not in the least regret that Cuwaert had lost his life.

Vrevel's sorry conclusion in Reinhart Fuchs foregrounds the problematic place of sentiment in any meditation on justice. The question of the relative weight of individual appeals finds echo in other scenarios in the tradition, not least in the scene cited above from the Middle Dutch Van den Vos Reynaerde in which Cuwaert the hare (a name derived from his Old

${ }^{14}$ On the Dutch adaptation in this regard, see my "“Oem walschedi?": Touching Teeth, Tongues and Skin in Van den Vos Reynaerde', Queeste: Tijdschrift over middeleeuwse Letterkunde in de Neerdelanden / Journal of Medieval Literature in the Low Countries, 18:1 (2011), special number: Reynaert Abroad: 'Van den vos Reynaerde' in International Perspective, 32-57. 
French prototype, Couart) is killed, a moment that has no equivalent in Reinhart Fuchs. ${ }^{15}$ Here, Goethe follows his source Gottsched, who in turn draws on the 1498 Lübeck version of the Low German fox epic. Like the Middle Dutch and the Low German versions, both Gottsched and Goethe have the fox reveal to his family that the hare, having conspired against them, is theirs in compensation to do with as they see fit (Van den Vos Reynaerde, 11. 3105-14; Gottsched Reineke der Fuchs, chapter 35; Goethe, Reineke Fuchs, VI, 11. 18589). ${ }^{16}$

In parallel to the attack's brutally cynical negation of courtliness, the emotional transformations both within versions of this scene and between them are highly loaded. Even as Reynaert appropriates the judicial function of the court, so, away from the palace, the courtly hare's gracious ('ghenadelike', Van den Vos Reynaerde, 1. 3121) appeal finds no sympathetic ear. By contrast, in Goethe's Reineke Fuchs (VI, 11.190-99), following Gottsched, Lampe's cry is pitiably frightful ('der laut und gräßlich um Hülfe | schrie' VI, 11. 193-94, emphasis added). At the same time, key to the fox's layered deception of the two courtiers accompanying him is the pathetic picture he paints of his wife's grief and worry. In Van den Vos Reynaerde, the fox bids Belin exhort Cuwaert to offer due comfort and

${ }^{15}$ The surviving versions contain a truncated pilgrimage narrative, see Flinn, Le 'Roman de Renart', pp. 562-55. However, it seems most improbable that this could have featured any analogous scenario. The hare is present in the final phase of Reinhart Fuchs, where, as with Coart in the Roman de Renart, he is terrified out of his wits by the King's anger (11. 148184). In Heinrich's narrative, the closer echo of Vrevel's lament is of the finding of the injured Isengrin in the woods, where the wolf weeps at seeing his wife and sons ('des frowete sich do Isengrin | weinunde er $\mathrm{zu}^{\circ}$ in sprach: | "alsus gerne ich ivch nie gesach | liebin sune unde wib, | io han ich uerlorn mien lip."”, 11. 610-14).

${ }^{16}$ Johann Christoph Gottsched, Reineke der Fuchs in Ausgewählte Werke, ed. by Joachim and Brigitte Birke, 12 vols (Berlin: de Gruyter, 1965-1995; repr. 2005), IV. 
consolation to the vixen and her cubs ('Heere Belin, bidt hem dat hi $\mid$ troeste wel vrauwe Hermelinen | met haren kleenen welpkinen', 11. 3079-81), a detail captured in both Gottsched's version and Goethe's (VI, 11. 172-74). The truth mediated in the lie is evident in the sincere concern and worry with which Hermeline - in Reineke Fuchs 'die traurige Füchsin [...] | von großer Sorge bezwungen' (VI, 11. 176-77) - greets her husband, only for such finer feeling to dissipate in a world in which the hare's life is blithely traduced away. As Reineke comments sardonically, 'Er ist wahrhaftig zum erstenmal etwas | Nütze, der alberne Geck' (VI, 11. 198-99). The only true worth of Lampe's existence lies in his death and disappearance.

The ambiguous reception accorded this pathetic scene continues graphically in Kaulbach's illustration (fig. 1). In contrast to Goethe's humanely modest antiquarian fidelity

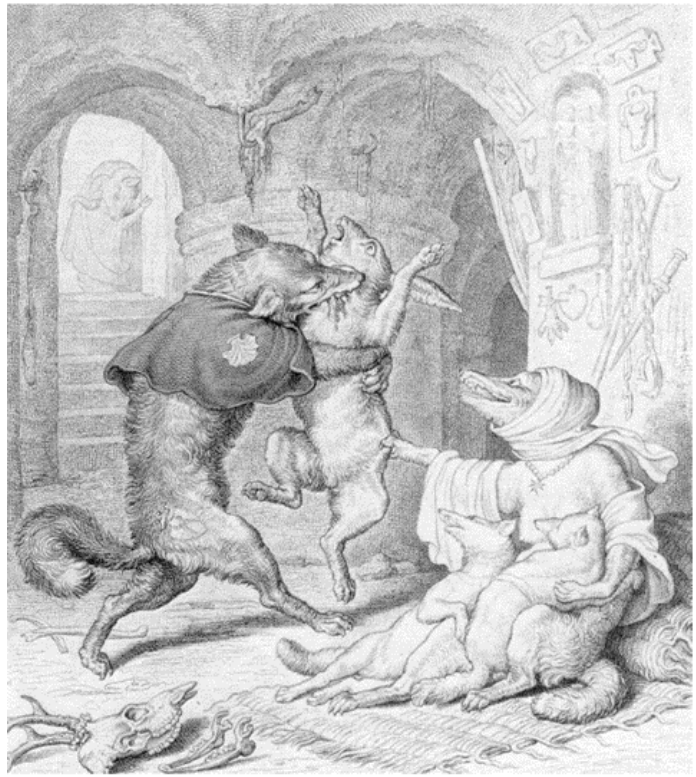

Figure 1 Kaulbach, Reineke murdering Lampe (sechster Gesang) to the cruel games played in his medieval sources, Kaulbach's images amplify and transform the ethical theatre of the beast epic. Staring out in recall of a last desperate plea, the hare's eye internalises the force of verbal appeal as a speaking character turns into a still (un)life. This harrowed muteness troubles our understanding of how animal images regard us in the double sense Jacques Derrida evokes in the French expression 'l'animal nous regarde'. ${ }^{17}$ The animal here

${ }^{17}$ Jacques Derrida, L'Animal que donc je suis, La Philosophie en effet (Paris: Galilée, 2006); The Animal that I Therefore Am, ed. by. Marie-Louise Mallet, trans. by David Wills, Perspectives in Continental Philosophy (New York: Fordham University Press, 2008). For 
'regards us' in the measure in which any admission on our part of the ethical weight of its suffering may lie in something other than a notional or even joking concession to a lesser creature. It 'regards' us in that its silence calls on us to supply words to translate its situation and suffering such that it can be given a fair hearing - if we care, that is.

Cast wide as if in desperate supplication, Lampe's forelimbs remind us that this scene originates in the fiction of an animal speech brutally silenced. Here flailing body and murderous suffering find themselves anthropomorphized and marshalled into rhetorical gesture. Against this, as macabre Hintergrund, the wall hooks appear festooned with animal parts, a decorative counterpoint also including the eyeless deer skull (figuring a negation of the hare's gaze) and its dislocated jawbone (as negation of voice) lying on the floor, as well as the outline animal forms adorning the walls. Motley lares et penates cluster in syncretistic assemblage around a domestic shrine. If Goethe followed Gottsched in conceiving of his poem as an 'unheilige Weltbibel' (as Goethe described it in 1793), then this space is its carnivorous temple. ${ }^{18}$ Both eyes and empty sockets emphasise how the hallway is crossed by various lines of sight: upper left, we see up the stairs out to the exterior, while to the right another hallway opens. Likewise, the domestic interior appears as an intersection of perspectives encompassing Belin peering in sheepishly from outside, his view eerily doubled upper right by a ram's head with identically curled horns staring down from the interior wall. Alongside these, we have the savage intent of the fox, the amused cruelty of vixen and cubs, and at the centre the encounter between spectator and multiply gestochen Lampe - engraved or skewered, as you will, in modern answer to the swiftly ('sciere') sheared throat of his

the German translation, see Das Tier, das ich also bin, trans. by Markus Sedlaczek, Passagen Forum (Vienna: Passagen, 2010).

${ }^{18}$ Goethes Werke, Weimarer Ausgabe (Weimar, 1887-1919), I Abteilung, 35, p. 22. 
medieval ancestor. Here every background cruelty seems given foreground life and presence: the inanimate wall hooks find their mockingly living counterpart in the vixen's claw

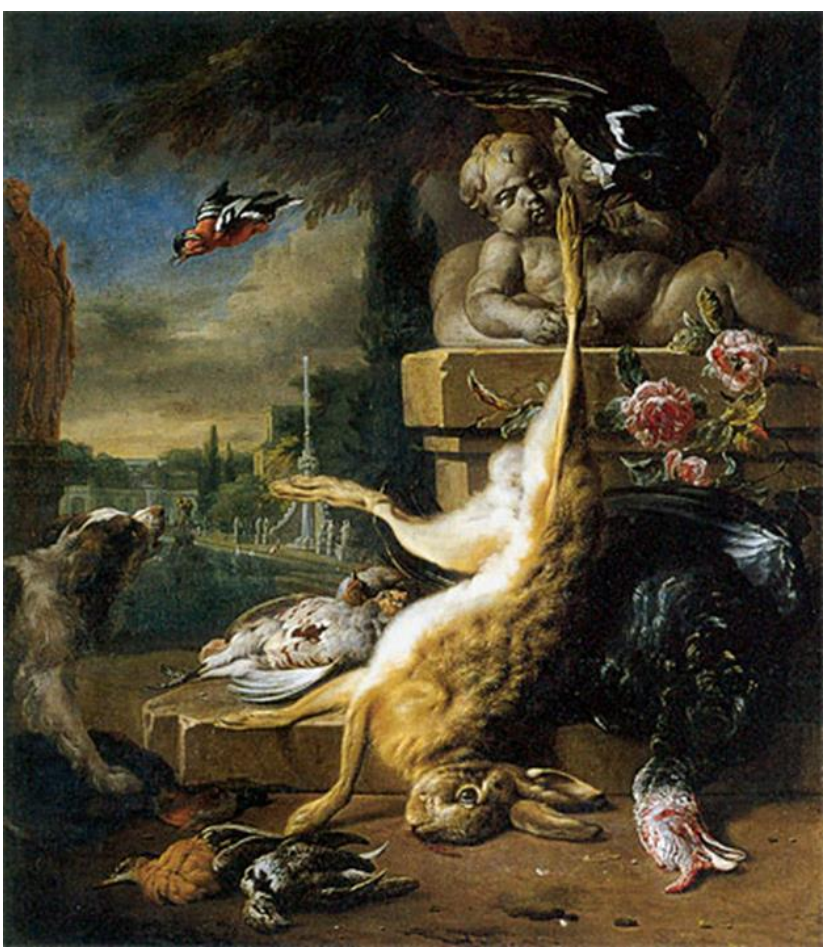

Figure 2 Jan Weenix, Dead Hare and Dog (1717) clutching at the hare's flank.

Composition and technique are fundamental to Kaulbach's framing of the issue of pathos. ${ }^{19}$ In many of the plates the centre-ground - often diamond-shaped stands out in sharp detail relative to the background. Objects find their focus in an art that homes in pointedly on such dehumanizing vices as mendacity and hypocrisy. This recurring organization paves the way for the ecce vulpis moment of the animals bowing to their newly

laureled Reichskanzler.

However, perhaps the most striking resonance here does not depend on either textual sources or the immediate visual medium. The central inversion here is that Lampe's pose notably the positioning of his forelimbs - offers a vertically flipped, animated mirroring of the still-life study of a dead hare. Examples of this set piece survive by artists such as Jan Weenix (?-1719; fig. 2), Alexandre-François Desportes (1661-1743), Dirk Valkenburg

${ }^{19}$ Correspondingly, it has been suggested that the parchment of medieval manuscripts can recall the cruelty of flaying. On this see Sarah Kay, 'Original Skin: Flaying, Reading and Thinking in the Legend of St Bartholomew and Other Works', Journal of Medieval and Early Modern Studies, 36 (2006), 35-74. 
(1675-1721) among others. ${ }^{20}$ However, not all such canvasses show hares with eyes open or the forelegs akimbo, which already hints that the pathos of Kaulbach's scene may derive in part from a choice of model. Even the detail of Lampe's distressed leaping on his hind quarters mimics a dead animal suspended by one leg, the other lolling limply down. ${ }^{21}$ Both feet are off the ground even as the wall hooks will serve to suspend his carcass, even as he now hangs as a dead animal resuscitated for the purposes of cruel amusement.

\section{The King Gives Tongue}

When we kiss, we devour the object by caressing it; we eat it, in a sense, but sustain its presence. $^{22}$

The emphasis on orality in court contexts is apparent at various points in Kaulbach's cycle, and in a manner that significantly extends and sharpens Goethe's satirical engagement with

${ }^{20}$ Weenix in particular produced numerous variations on this subject.

${ }^{21}$ In a kind of creative serendipity, Kaulbach thereby captures how such handling thematises processes of transmission and reworking in the beast epic tradition. Thus, just as in one episode, the seemingly dead fox is turned this way and that by some merchants examining his pelt before tossing him into their cart (from where he is able to make off with a haul of fresh eels), so we also see variations between manuscript versions of the same passage, the scenarios described being themselves flipped in rewriting. On this subject, see my "“Oem walschedi?": Touching Teeth, Tongues and Skin in Van den Vos Reynaerde', Queeste: Tijdschrift over middeleeuwse Letterkunde in de Neerdelanden/ Journal of Medieval Literature in the Low Countries, 18 (2011), special number: Reynaert Abroad: 'Van den vos Reynaerde' in International Perspective, pp. 32-57 (pp. 44-45).

${ }^{22}$ Adam Philips, On Kissing, Tickling and Being Bored (London: Faber and Faber, 1993), p. 103. 
court ideals. In my reading of Lampe's murder, I principally highlighted the negation of the hare's voice. However, one might equally turn attention to the effect on the fox. In biting Lampe's throat, Reineke silences himself as a speaking subject - a consideration foregrounded in the motif of the cockerel, Chantecler, escaping the fox's jaws by getting him to speak. ${ }^{23}$ However, such a silencing operates and resonates differently in text and image. Thus Kaulbach's spectacular underscoring of bite over bark (or shriek, for that matter) resonates at least as strongly as the text's verbal subterfuge alleging that it is right that the hare should be at the mercy of the fox.. This irony is exacerbated by the rapid transformation of his sorrowing wife into a cruelly amused accomplice. One detail to note here is how the vixen's marginal position in relation to the central drama partakes of both foreground and background: while she is sharply drawn, her position is tied compositionally to the less sharply executed carvings and paraphernalia hanging from the wall above her. Thus her emotional transformation is doubled by a visual one, whereby the walls that define Reineke's domestic sphere appear to be coming to life.

By way of extending this consideration of the relation between life, the body, appetite and speech, I would like to turn to Kaulbach's grotesque evocation of court festivity early on in the siebenter Gesang. This particular illustration departs significantly from Goethe's text:
Aber Reineke Fuchs lag auf der Lauer zu Hause,
Dachte nicht nach Hofe zu gehn, der verlogene Pilger;
Wenig Dankes erwartet' er sich. Nach altem Gebrauche
Seine Tücke zu üben, gefiel am besten dem Schelme.

\footnotetext{
${ }^{23}$ For text, see Le Roman de Renart, ed. by Jean Dufournet, trans. by André Meline, 2 vols (Paris: Garnier Flammarion, 1985), I (Br. II, 11. 418-59).
} 
Und man hörte bei Hof die allerschönsten Gesänge,

Speis und Trank ward über und über den Gästen gereichet,

Und man sah turnieren und fechten. Es hatte sich jeder

$\mathrm{Zu}$ den Seinen gesellt, da ward getanzt und gesungen,

Und man hörte Pfeifen dazwischen und hörte Schalmeien.

Freundlich schaute der König von seinem Saale hernieder;

Ihm behagte das große Getümmel, er sah es mit Freuden.

(Reineke Fuchs, VII, 11. 12-22)

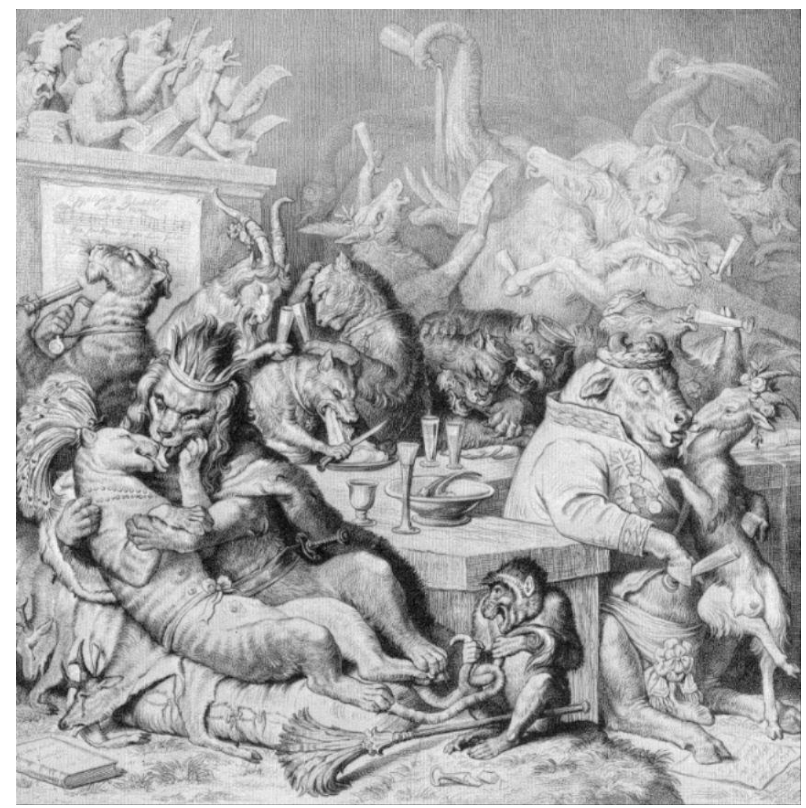

Figure 3 Kaulbach, The Court Orgy (siebenter Gesang)
I can think of no direct literary precedent for Kaulbach's court orgy scene, the baroque extravagance of its massing of bodies offering a convenient summation of the turbulent forces at work in the illustrator's anthropomorphism.

As part of this image's bestial turn, one of the more strikingly grotesque details

here is that of the lion and lioness kissing or, rather, licking one another's tongues (figs 3 and 4). Here the kiss - which as Adam Philips puts it, devours the object without eating it - is caricatured in bestial avatar. Thus the political tragedy signified through the tragic sundering of Vrevel's tongue in Reinhart Fuchs here finds a late bestial echo in Kaulbach's scandalous queering of human and animal. The commentary on this corrupted vision appears directly above in the vignette of the imminent suicide of the lioness courtier who appears as displaced 
rival to the King's paramour. Here the inversion takes the form of the pistol turned back against its holder, a detail mirrored in the despairing set of the lioness' mouth and her backwards glance down at the new royal couple. In Kaulbach's universe, a vision of the suicidal lioness with her brains blown out - in female echo of the suffering Werther - or, indeed, the King deploying something other than his tongue might have been a step too far, the illustrator instead thoughtfully keeping us with a kiss and a comic anticipation of (animal) tragedy. At this point we would have an intriguing variation on the scenario at the end of Reinhart Fuchs, wherein the shattered skull and debased tongue would be associated with two lions rather than one.

The hubbub evident around the King evidently reflects a concern with the fate of royal authority and legitimacy as

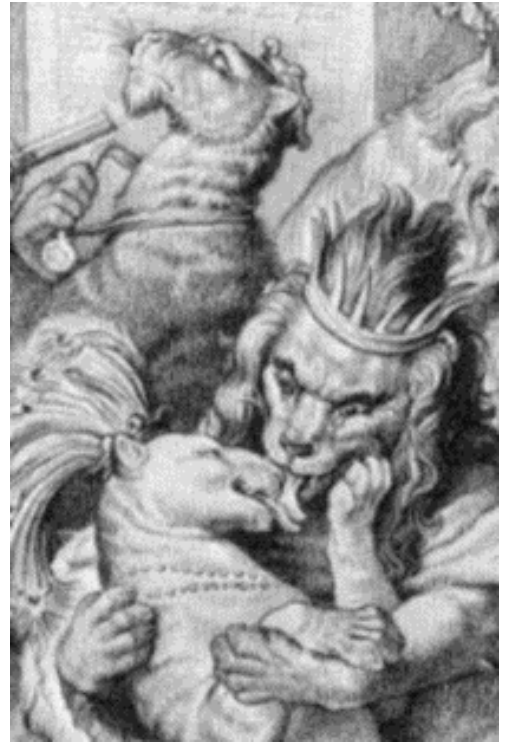

Figure 4 Kaulbach, The Court Orgy (detail) mediated by pronouncement: this is not what the royal tongue is for. Again here the composition itself speaks volumes: the king is somewhat displaced from the centre of the composition, relegated almost to the status of a marginal decoration, a detail also foregrounded in the monkey's gesture of plaiting his and the lioness's tails together in a manner reminiscent of a decorative marginal interlace. Against this, although not part of the detailed foreground, we have the beastly cacophony of the choir as the emergent voice of the animal court. The emphasis on the body locates the royal kiss as a perverse orality, its entwining debasing any ideals of the relation between pathos and language, reducing courtly language to a decadent bestiality.

The king's compositional displacement also sets the stage for a doubling apparent in the balancing echo between the two lions to the left and the grotesquely mismatched bull and she-goat to the right of the image. Although ostensibly part of the sharply etched foreground, 
the lighter tone of this part of the engraving gives them lesser emphasis. However, this tonality is mockingly offset by a striking use of both echo and difference: the incongruity of species and build is counterpointed by the mirrored kiss. Meanwhile, the relative positions of the lion couple are flipped, the she-goat positioned left and the bull right. At this point the former's pendulous udders prominently displayed in bipedal stance appear almost as a scrotal sac, a duplicity rendered all the more acute by the prominent absence in the representation of the bull, his genital region discreetly covered by a sash, even if there is something quietly indecent about the position and angle of the champagne flute.

Such sardonically intense satirical play on unbridled cruelty and lust chimes with a more general motif in Kaulbach's illustrations. His animals appear naked insofar as they are frequently depicted partly clothed or taking on guises (notably Reineke's pilgrim cloak, which features in a sub-sequence). The illustration of Reineke at home in bed regaling his wife with tales of his adventures plays with the intimacy of private space in order to reflect on the furry nakedness of the animal: here fox and vixen are coyly distinguished by the minimal remnants of bedroom attire, nightcap and hairband. Such toying with naturalism and human attitudes is arguably part of a reflection on value and decorum that explores various moods, from savagery and debauchery to playful repose.

\section{Carolingian Animals}

Quapropter ego esse mihi utile dico

Quod gessi purgare prius; sua quemque sequentur

Contemplatur itemquendam lustrata per arva, Ausoniae quondam qui regna tenebat et altae Romae gentis, fixo consistere gressu, 
Oppositumque animal lacerare virilia stantis.

Laetaque per reliquum corpus lue membra carebant. (Strabo, 11. 444-60) ${ }^{24}$

Hence for my own part I maintain that it is practical to atone for my acts beforehand. Every man will be dogged by his own deeds. He also observed among illumined fields one who once had held imperial sway over Ausonia and the exalted Roman people. He was rooted to the spot, and in front of him an animal was tearing at his genitals as he stood there. The limbs on the rest of his body were blessedly free from laceration.

The problems highlighted by Heinrich and in the graphic cruelty of Kaulbach's illustrations can be located in a much larger historical critical and cultural frame. ${ }^{25}$ Looking in a contemporary direction, we might turn to the field of biopolitics or indeed Edward O. Wilson's concept of 'biophilia' - defined as the human tendency to 'affiliate' with other forms of life - and subsequent related discussions. ${ }^{26}$ However, by way of a conclusion here, I would look back instead. The above citation from Walafrid Strabo's ninth-century vision of Charlemagne tortured in hell for his sexual transgressions suggests affinities with the beast

\footnotetext{
${ }^{24}$ Walafrid Strabo, Walahfrid Strabo's 'Visio Wettini': Text, Translation and Commentary, ed. and trans. by David A. Traill, Lateinische Sprache und Literatur des Mittelalters, 2 (Bern: Herbert Lang, 1974).

${ }^{25}$ On which see, among many others, Giorgio Agamben, The Open: Man and Animal, Meridian: Crossing Aesthetics (Stanford: University of Stanford Press, 2004); Jane Bennett, Vibrant Matter: A Political Ecology of Things (Durham: Duke University Press, 2010); Matthew Calarco, Zoographies: The Question of the Animal from Heidegger to Derrida (New York: Colombia University Press, 2008); Anat Pick, Creaturely Poetics: Animality and Vulnerability in Literature and Film (New York: Cornell University Press, 2011).

${ }^{26}$ Edward O. Wilson, Biophilia (Cambridge, MA: Harvard University Press, 1984).
} 
epic tradition. At one level, the imagery of the medieval beast epic could be interpreted in the light of Carolingian claims to political and judicial authority. According to Hincmar of Reims, propagandist for Charles the Bald, the palace's political vitality depends on its status as a locus of just and rational speech and reflection: 'The palace of the king is so called because of the rational men who inhabit it, not because of its insensible walls and enclosures' ${ }^{27}$ Hincmar's treatise On the Governance of the Palace elaborates further on the open organization of the Carolingian palace, animated by the presence of the sovereign through the representation of his counsellors. ${ }^{28}$ Animals played an important symbolic role in the palace because they illustrated its openness to 'more people, questions and things' ${ }^{29}$ Exotic creatures, such as the elephant Charlemagne took on his Saxon campaign, arrived as gifts. ${ }^{30}$ Meanwhile, De ordine speaks of the officers of the royal hunt rubbing shoulders with

27 'Palatium enim regis dicitur propter rationabiles homines inhabitantes, et non propter parietes insensibiles sive macerias.' Hincmar of Reims, letter, in Concilia Aevi Karolini DCCCXLIII-DCCCLIX, M.G.H., Concilia III, ed. by Wilfried Hartmann (Hanover: n.p., 1984), p. 412, trans. by J.S.. For comment, see Stuart Airlie, 'The Palace of Memory: The Carolingian Court as Political Centre', in Courts and Regions in Medieval Europe, ed. by Sarah Rees Jones, Richard Marks and Alastair J. Minnis (Woodbridge: Boydell and Brewer, 2000), pp. 1-20 and also Josiane Barbier, 'l'Évêque et le palais', in La Correspondance d'un évêque carolingien: Frothaire de Toul (ca. 813-847): avec les lettres de Theuthilde, abbesse de Remiremont, ed. by Michel Parisse (Paris: Publications de la Sorbonne, 1998), pp. 27-40.

${ }^{28}$ For text, see Hincmar de Rheims, De ordine palatii, ed. and trans. by Maurice Prou (Paris: Vieweg, 1884); for translation, see Hincmar, 'On the Governance of the Palace', trans. by David Herlihy, in A History of Feudalism, ed. by Herlihy (London: MacMillan, 1970), pp. 208-27. See $\S 25$.

${ }^{29}$ Jennifer R. Davis, Charlemagne's Practice of Empire (Cambridge: Cambridge University Press, 2015), p. 171.

${ }^{30}$ On Charlemagne's animals and their geopolitical significance, see Mary W. Helms, Ulysses' Sail: An Ethnographic Odyssey of Power, Knowledge and Geographical Distance 
the higher functionaries. ${ }^{31}$ But then, as we see from Strabo's account of the emperor tortured in afterlife, Charlemagne was associated with animals for other reasons, leaving a sense that the propaganda could backfire. Here the suggestion seems to be that the palace was less an open, virtuous place than a closeted haven of unspeakable secrets. ${ }^{32}$

It is clear that Carolingian ideals had an important afterlife in discussions of palace decorum and political function in the central Middle Ages. ${ }^{33}$ The animal imagery seems to have had an afterlife as well. Louis IV is said to have been fatally injured having fallen from his horse at the sight of a monstrous wolf, this, as Flodoard suggests, perhaps specifically in divine retribution for his brutal attack on Corbeny in 938, but also as a reflection of a more general curse on the dynasty. ${ }^{34}$ Slightly later, we see Charlemagne troubled by animal dreams

(Princeton: Princeton University Press, 1988). On the elephant in particular, see Rosamond McKitterick, Charlemagne: The Formation of a European Identity (Cambridge: Cambridge University Press, 2008), pp. 286-87.

${ }^{31}$ See Hincmar, Governance, § 16-17.

${ }^{32}$ As Stuart Airlie comments, 'even the angel Gabriel, when he wishes to send an urgent spiritual message to Louis the Pious, is described as going through the proper channels and understanding the need to have a patron at court.' Airlie, 'Bonds of Power and Bonds of Association in the Court Circle of Louis the Pious', in Charlemagne's Heir: New Perspectives on the Reign of Louis the Pious (814-840), ed. by Peter Godman and Roger Collins (Oxford: Oxford University Press, 1989), pp. 191-204, p. 195.

33 On the importance of Carolingian models for later constructions of courtliness, see C. Stephen Jaeger, The Envy of Angels: Cathedral Schools and Social Ideals in Medieval Europe, 950-1200, The Middle Ages (Philadelphia: University of Pennsylvania Press, 1994). ${ }^{34}$ See The Annals of Flodoard of Reims, 919-966, ed. and trans. by Steven Fanning and Bernard S. Bachrach. Readings in Medieval Civilizations and Cultures, 9 (Peterborough: Broadview, 2004). 
in the Oxford version of the Chanson de Roland, a text in which the legend of the emperor's incestuous relation with his sister has been characterized as a looming silence. ${ }^{35}$

Hincmar's ideal of living walls can certainly be located in a genealogy of discussions of decorative and iconographical programmes down the ages. Here we find suggestive parallels in Kaulbach's public commissions, their underpinning engagements affording a glimpse of what was at stake in Reineke Fuchs. As Werner Busch observes, Kaulbach's grand sequence of canvasses for the south wall of the Treppenhaus (grand staircase) in the Neues Museum, Berlin, is juxtaposed with a decorative frieze. ${ }^{36}$ Herein lies a central facet of the relation between historical panorama and the immediate philosophical and political concerns of the 1850s:

Im Fries (Abb. 4) tummeln sich in arabesken Pflanzenformen Kinder- und Tiergestalten und geben einen fortlaufenden ironischen Kommentar zur darunter sich ereignenden Welt- und Kulturgeschichte der Menschheit ab. Deren punktuelles Pathos relativiert sich angesichts des natürlichen Flusses der Zeit, versinnbildlicht durch den gleichförmigen Rhythmus der Arabeske. Die handelnden Personen der Geschichte werden also einerseits als Träger der Ideen des Weltgeistes begriffen, andererseits als Marionetten der Natur. In der Realität scheint dieser Widerspruch unaufhebbar. Kann die Kunst mit ihren Mitteln die Gegensätze versöhnen? Die Frühromantiker hätten das

${ }^{35}$ For my earlier comments on animal imagery in the Roland tradition, see "'Uns uers si mals": H. R. Giger et les animaux de cour dans la Chanson de Roland', in In Limine Romaniae: chanson de geste et épopée européenne, ed. by Carlos Alvar and Constance Carta (Bern: Peter Lang, 2012), pp. 39-60.

${ }^{36}$ These were destroyed during the Second World War. For contemporary reproductions, see Friedrich August Stüler, Das neue Museum in Berlin: 24 Tafel (Potsdam: Riedel, 1862). 
ohne zu zögern bejaht und auf die den universalen Zusammenhang stiftende Funktion der Ironie verwiesen.

Kaulbach, so unsere These, scheint das zu bezweifeln. Die Hegelianer, anders als Hegel, scheinen der Kunst in ihren Abhandlungen der fünfziger Jahre immer noch ohne allzu große Komplikationen diese Fähigkeit der Versöhnung zuzuschreiben. ${ }^{37}$

Whatever degree of doubt or certainty one might see in the contrast between the stern awe of the Treppenhaus central programme and the playfulness of the decorative friezes, Kaulbach's Reineke illustrations offer still less optimistic perspectives on any hope of reconciliation between human and animal, pathos and irony. Here the relation between foreground and background is disquietingly destabilized, a mockery reminiscent of Hegel's night of the world, its dreadful 'simplicity' ('Einfachheit') filled with gruesome membra disjecta. ${ }^{38}$ Thus, just as the medieval sources and Goethe's version feature any number of false legal Versöhnungen between warring creatures, so a kindred devilish response to any possible philosophical reconciliation looms in Kaulbach's compositions. Accordingly, the pathos, humour and irony evident in Kaulbach's grand canvasses - already pointed in their engagement with contemporary discussions of relations between history and representation -

${ }^{37}$ Werner Busch, 'Wilhelm von Kaulbach: peintre philosophe und modern painter', in Welt und Wirkung von Hegels Ästhetik, ed. by Annemarie Gethmann-Siefert, Hegel-Studien; 27 (Bonn: Bouvier, 1986), pp. 117-38 (pp. 125-25).

${ }^{38}$ G. W. F. Hegel, 'Jenaer Realphilosophie', in Frühe politische Systeme (Frankfurt: Ullstein 1974), p. 20. In this connection, see for example the final illustration of the sechster Gesang. Here we have the unfolding actions of the brutal execution of Bellyn the Ram in the foreground and, in the background, the sheep divided between seemingly equally risible and futile flight from the court and prayer to a saint's shrine. Shrines feature in a number of the illustrations, thus questioning the utility of religion. 
are crucially problematized in satirical studies and sequences such as the Narrenhaus and Reineke Fuchs, where suffering blurs into beastly indifference and madness. The problematic place of the animal in that structure, as a cipher for an encompassing mercy and purpose extending to all God's creatures, is then as a terrain to which 'existence' can be extended, but in a manner that is inevitably provisional, unstable and uncertain. Satirically or reflectively, we might be inclined not to take the dying Vrevel and Lampe seriously and so see in the fiction of animal language nothing more than an empty dream.

\section{Conclusion}

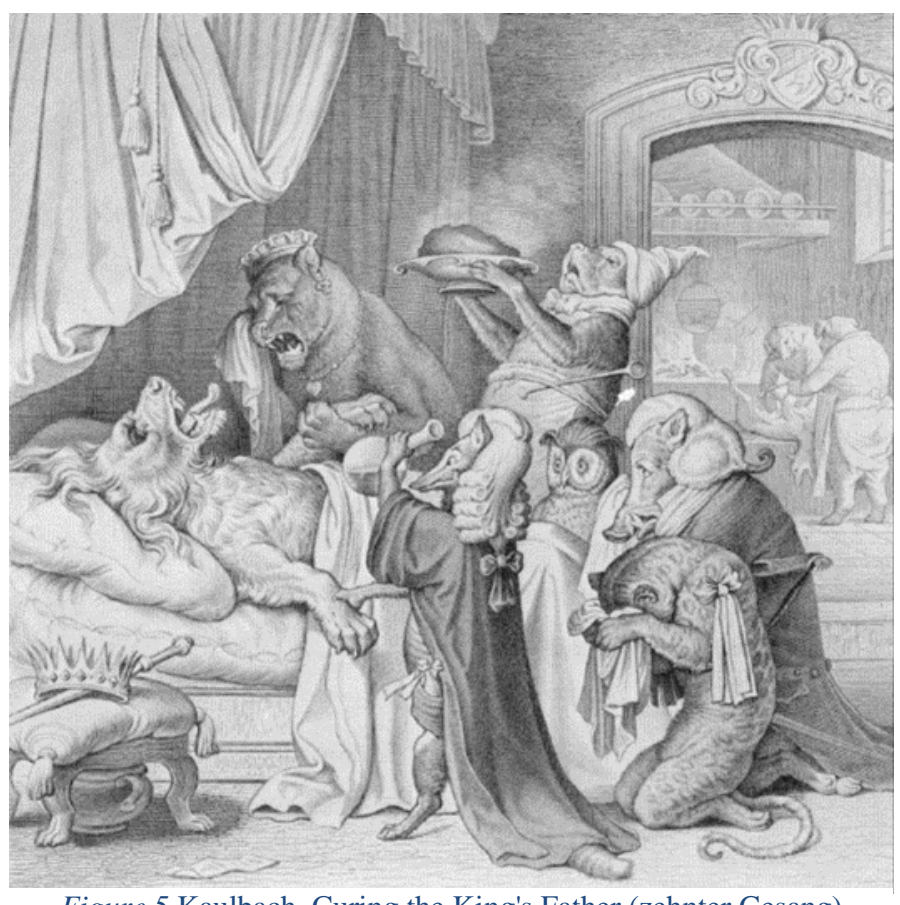

Figure 5 Kaulbach, Curing the King's Father (zehnter Gesang)
Unlike Heinrich, neither Gottsched nor Goethe killed their lion king. However, although Goethe's text could not be altered, it could be reinflected, with Kaulbach's illustration accompanying the zehnter Gesang (fig. 5) offering us a flitter of regicide. The lion-king's father lies on his bed, surrounded by anxious, grieving onlookers. Where in other illustrations, the pathetic attitudes of sick or injured animals find sympathy in the concern of their kin, here the lion's black and lifeless eyes and lolling tongue indicate a creature who can no longer speak or return a gaze. One might be inclined to believe him dead, but death is merely a joking spectre here, as the lion is about to be revived by the meal of wolf's liver prescribed by the fox. Meanwhile, as the fox in a doctor's wig looks quizzically at a urine sample, the royal regalia sit on a nearby 
stool under which there is a chamber pot. ${ }^{39}$ There may be some implicit reflection on the relation between the king's two bodies (the legal/political persona as opposed to the actual individual), though how seriously we are to understand it is another matter. Eclipsed by the tragi-comic scene in the foreground, the suffering and death of the wolf butchered in the kitchen goes ignored.

As a death sentence in appearance only (except for the wolf, of course), Kaulbach's scene contrasts directly and tellingly with Reinhart's lapidary warning to Crimelen the badger, 'der kvnic mac niht genesen' ('the king has no hope of recovery' 1.2195). ${ }^{40}$ In Heinrich's dramatic image of death and Zerfall, one possible understanding is that the fox's act brutally kills both royal bodies: person and idea. Or perhaps the comment highlights a fateful ambiguity attaching to the King's position caught between the realities of death and continuing power, his susceptibility to poisoning recalls how the figure of Charlemagne can symbolize both merciful compassion and venal frailty. In a similar way, Kaulbach's deference to Goethe's text means that the image of the death (and resurrection) of the lionking's father merely provides a conveniently 'backwritten' double for the present ruler: the king is (not really) dead, so long live him. However, Goethe's text makes no mention of the obscene kiss in the siebenter Gesang, the lion's grotesque tongue there becoming one visual precursor to the spectacle of his seemingly moribund ancestor. As with Vrevel's lament or the fear and suffering of the hare, the violence of the beast epic marks a debasement of pathos as providing meaningful voice to the fate of the body. In contrast to Heinrich's cruel vision of

39 This perhaps recalls Heine's Deutschland. Ein Wintermärchen, Caput XXVI, where Hammonia's cauldron is Charlemagne's chamber pot. Heinrich Heine, Sämtliche Schriften, 6 vols, ed. by Klaus Briegleb (Munich: Hanser, 1978), IV, p. 638.

${ }^{40}$ As with the Middle High German noun der magen ('power', 'capacity'), the modal verb has a force equivalent to Modern German können. 
empty animal verbiage, in Kaulbach's illustrations, bitten throats and silent tongues speak volumes about such animal stifling, giving graphic expression to the idea that at any moment an individual voice can either be silenced - casually or brutally - or simply not heard. 